\title{
Frozen subduction in the Yangtze block: insights from the deep seismic profiling and gravity anomaly in east Sichuan fold belt
}

\author{
Xiaosong Xiong $\cdot$ Rui Gao $\cdot$ Haiyan Wang $\cdot$ Jisheng Zhang $\cdot$ \\ Lianghui Guo
}

Received: 9 October 2015/Accepted: 7 January 2016/Published online: 9 April 2016

(c) The Author(s) 2016. This article is published with open access at Springerlink.com

\begin{abstract}
The Sichuan basin is the main part of the middle-upper Yangtze block, which has been experienced a long-term tectonic evolution since Archean. The Yangtze block was regarded as a stable block until the collision with the Cathaysia block in late Neoproterozoic. A new deep seismic reflection profile conducted in the eastern Sichuan fold belt (ESFB) discovered a serials of south-dipping reflectors shown from lower crust to the mantle imply a frozen subduction zone within the Yangtze block. In order to prove the speculation, we also obtain the middle-lower crustal gravity anomalies by removing the gravity anomalies induced by the sedimentary rocks and the mantle beneath the Moho, which shows the mid-lower crustal structure of the Sichuan basin can be divided into eastern and western parts. Combined with the geochronology and Aeromagnetic anomalies, we speculated the Yangtze block was amalgamated by the West Sichuan and East Sichuan blocks separated by the Huayin-Chongqing line. The frozen subduction zone subsequently shifted to a shear zone accommodated the lower crustal shortening when the decollement at the base of the Nanhua system functioned in the upper plate.
\end{abstract}

X. Xiong · R. Gao $(\bowtie) \cdot$ H. Wang · J. Zhang $\cdot$ L. Guo

Key Laboratory of Earth Probe and Geodynamics, MLR, Institute of Geology, Chinese Academy of Geological Sciences, Beijing 100037, China

e-mail: benxung@126.com; xung@cags.ac.cn

L. Guo

School of Geophysics and Information Technology, China

University of Geosciences, Beijing 100083, China
Keywords Sichuan basin - Frozen subduction - Deep seismic reflection - Gravity anomaly

\section{Introduction}

Deep seismic profiling images the frozen subduction zone within the continental lithosphere, including the first discovery of the Paleoproterozoic subduction-related structure in the Svecofennian orogen $(1.89 \mathrm{Ga})$ (BABEL Working Group 1990), the oldest relict suture associated with subduction $(2.69 \mathrm{Ga})$ (Calvert et al. 1995), and other relict plate convergence, subduction or accretion (Cook et al. 1999; Juhlin et al. 2002; Warner et al. 1996; White et al. 2000; Yuan et al. 2003). The seismic reflectors which extend from lower crust, cross the Moho, and dip and penetrate the mantle are widely suggested to be the relict subduction zones, in particular in the stable cratons (Warner et al. 1996), which did not undergo strong postcollisional deformation or magmatism. Yangtze block, one of the two main units of South China continent that was amalgamated by Yangtze and Cathaysia blocks at ca. 0.82 Ga (Charvet 2013; Zhao and Cawood 2012), has the Archean basement outcropped in northwestern and southwestern parts and George dam area (Greentree and $\mathrm{Li}$ 2008; Qiu et al. 2000; Wu et al. 2012), Yangtze block was thought to be a stable block since the early Precambrian, nevertheless, the Sm-Nd dating and geochemical research of the Yangtze block unraveled the distinctive difference features between the northern and the southern part $(\mathrm{Wu}$ et al. 2012), which inspired the debate of the Yangtze block as a stable unit.

From October 2010 to May 2011, we acquire a $550 \mathrm{~km}$ deep seismic reflection profile from the sub-project of Deep Exploration in China (SinoProbe02), with high-quality to 


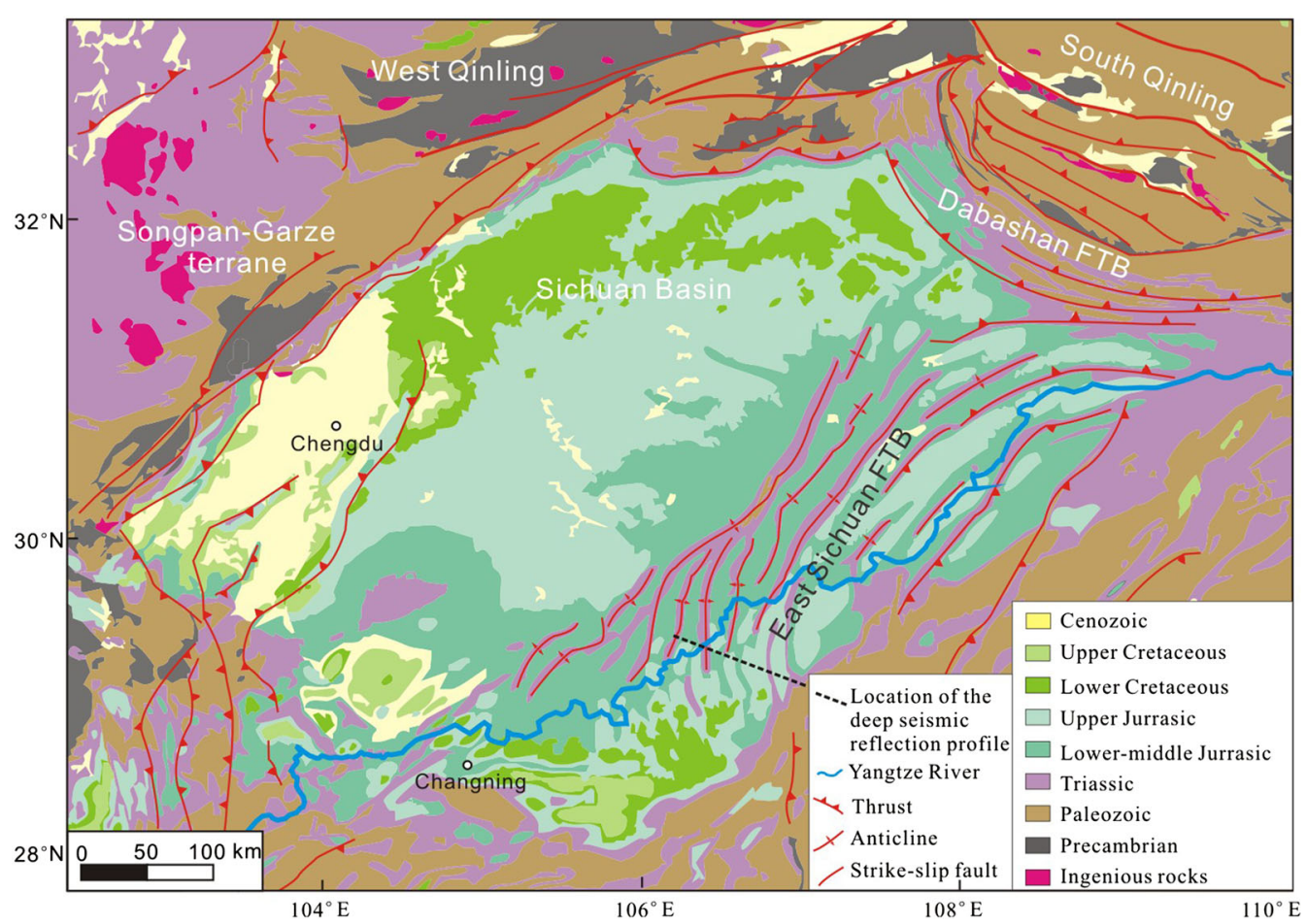

Fig. 1 Geological map of the Sichuan basin and adjacent regions (modified from 1:1000,000 geological map of China, http://ogc.cgs.gov.cn)

reveal reflective holistic crust. The most unexpected crustal structure revealed is the prolonging and east-dipping of the middle-lower crustal reflectors into the mantle shown beneath the eastern Sichuan fold belt (ESFB) in the westernmost $90-\mathrm{km}$-long seismic reflection profile. The finding is in consistent with the result of the deep seismic reflection profile to the north of this survey line (Gao et al. 2013). Gravity anomalies is a useful method to study the crustal density distribution structure and tectonics. We stripped the gravity anomalies induced by the sedimentary rocks and the mantle beneath the Moho to obtain the residual gravity anomalies, which represent the inhomogeneous density distribution of the middle-lower crust of the basin. The result verified the discovery of the deep seismic reflection profile (Xiong et al. 2015b).

\section{Regional geology}

As one of the largest and most complex Archean blocks in China, the Yangtze block consists of Archean-Paleoproterozoic crystalline basement (mostly hidden) surrounded by late Mesoproterozoic to early Neoproterozoic fold belts, which are locally unconformably overlain by middle Neoproterozoic weakly metamorphosed strata and late Neoproterozoic unmetamorphosed Sinian cover (Zhao and
Cawood 2012). The exposed basement consists dominantly of Proterozoic rocks, only sparse outcrops of Archean rocks along the western and northern margins of the Yangtze Block (Fig. 1). With the development of isotopic analytical technology, nevertheless, more and more Archean crustal materials have been identified (Jiao et al. 2009; Qiu et al. 2000; Zheng et al. 2006), which suggests that older basement may be widespread beneath the many parts of the Yangtze block (Wang et al. 2013; Zhang et al. 2006a; Zheng et al. 2006), the Lengjiaxi and equivalent group, used-considered Mesoproterozoic, are Neoproterozoic according to SHRIMP dating with a limit at $0.82 \mathrm{Ga}$ overlying by the Banxi group $(0.82-0.75 \mathrm{Ga})$, the folded basement of the Yangtze block finalized after the Jinning movement (Guo et al. 1980; Zhou and Zhu 1993; Charvet et al. 1996, 2013), on top of which are over 10-km thick sedimentary rocks covered most of the Yangtze block from Neoproterozoic to Cenozoic, including Nanhua system (0.75-0.635 Ga), Sinian (Ediacaran) system (0.635-0.542) and the Phanerozoic strata. The ESFB was typical thin-skinned thrust belt, with two types of compressive deformation structure: the Chevron anticline (box syncline) type to the northwest and the chevron syncline (box anticline) type to the southeast separated by the Qiyue fault on the surface. The core of the comb-like folds is Triassic layers, and the limbs of the folds are Jurassic layers outcropped (Fig. 2). 


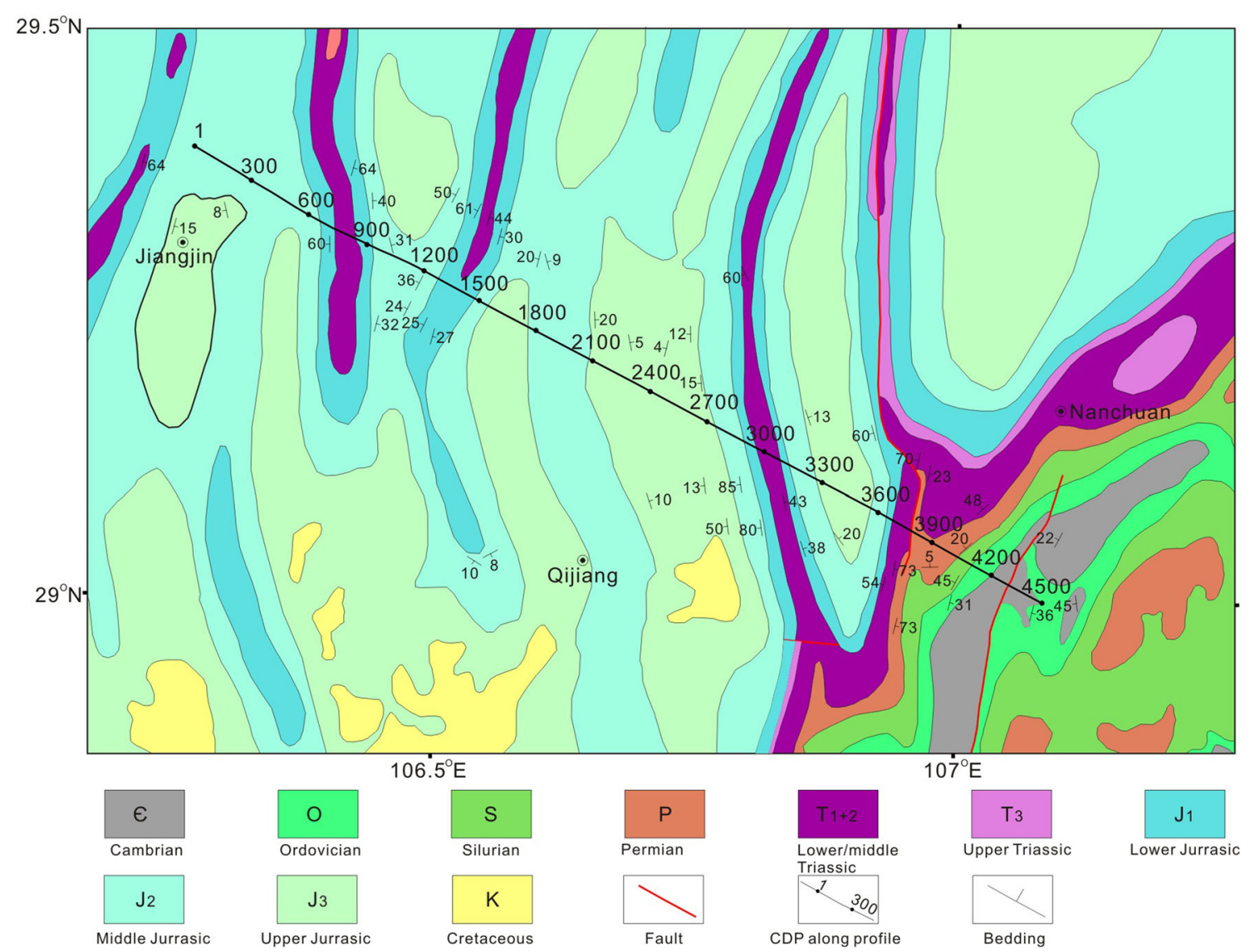

Fig. 2 The detailed geological map of the eastern Sichuan fold belt (ESFB) shown the location of the $90 \mathrm{~km}$ segment of the profile

\section{Seismic profiling}

The $90 \mathrm{~km}$ seismic profile is from Jiangjin, Chongqing, and continues southeastward to the east of Nanchuan, Chongqing. It mainly contains two tectonic elements, including the Chevron anticline (box syncline) type to the northwest and the chevron syncline (box anticline) type to the southeast separated by the Qiyue fault.

\subsection{The acquisition and processing of the seismic profile}

It was recorded with a Sercel $408 \mathrm{XL}$ acquisition system using $12 \mathrm{~m}$ long linear arrays of 24 geophones deployed every $40 \mathrm{~m}$, the shots with 48,100 and $500 \mathrm{~kg}$ were deployed spacing 280, 1000 and $5000 \mathrm{~m}$ respectively, the single-hole was drilled $30 \mathrm{~m}$ deep, and the recording length is $30 \mathrm{~s}$ (Table 1). A conventional processing sequence was applied to the data: refraction statics, crooked line binning, minimum phase conversion, dynamic equalization, spiking deconvolution, velocity analysis, normal moveout mute, surface consistent residual statics and post-stack migration.
This acquisition and processing methods permit the detailed crustal features.

\subsection{The main features of the seismic profile}

The seismic profile shows four significant features (Fig. 3): (1) the strong deformed sedimentary cover underlain by the regional structural unconformity at a depth of $\sim 10 \mathrm{~km}$ (3.5 s); (2) the transparent middle crust with some weak downto-south reflectors; (3) southward-dipping reflectors from the lower crust to the lithosphere mantle in the northernmost segment and near-horizontal reflectors in the middle segment; (4) the laminated reflectors at the base of the lower crust.

\subsubsection{Sedimentary cover $(<12 \mathrm{~km})$}

A regional structural unconformity at a depth of ca. $10 \mathrm{~km}$ is below the sedimentary cover. We assign the unconformity at the base of Nanhua group (Neoproterozoic strata) based on the regional stratigraphy, Pervasively folded strata with open anticlines and tight synclines are truncated by the decollement at the bottom of the Permian strata. 
Table 1 The detailed acquisition parameters

\begin{tabular}{llll}
\hline Receiver & & Source & \\
\hline Recording system & Sercel 408XL & Source type & Dynamite \\
Sample interval & $2 \mathrm{~ms}$ (normal) & Single well depth & $25 \mathrm{~m}(\mathrm{normal})$ \\
& $4 \mathrm{~ms}$ (large) & & $40 \mathrm{~m}($ large) \\
Number of receiver channels & 720 & Shot energy & $48 \mathrm{~kg}(\mathrm{normal})$ \\
Receiver group spacing & $40 \mathrm{~m}$ & & $100 \mathrm{~kg}($ large) \\
Number of geophones per group & 24 & Source spacing & $280 \mathrm{~m}$ (normal) \\
Spread configuration & Symmetric split-spread (normal) & & $5000 \mathrm{~m}$ (large) \\
& Off-end spread (large) & Recording & $30 \mathrm{~s}$ \\
Minimum offset & $140 \mathrm{~m}$ & Recording length & Recording format \\
Total spread length & $28.8 \mathrm{~km}$ & & SEG-D \\
Stacking fold & 50 & & \\
\hline
\end{tabular}

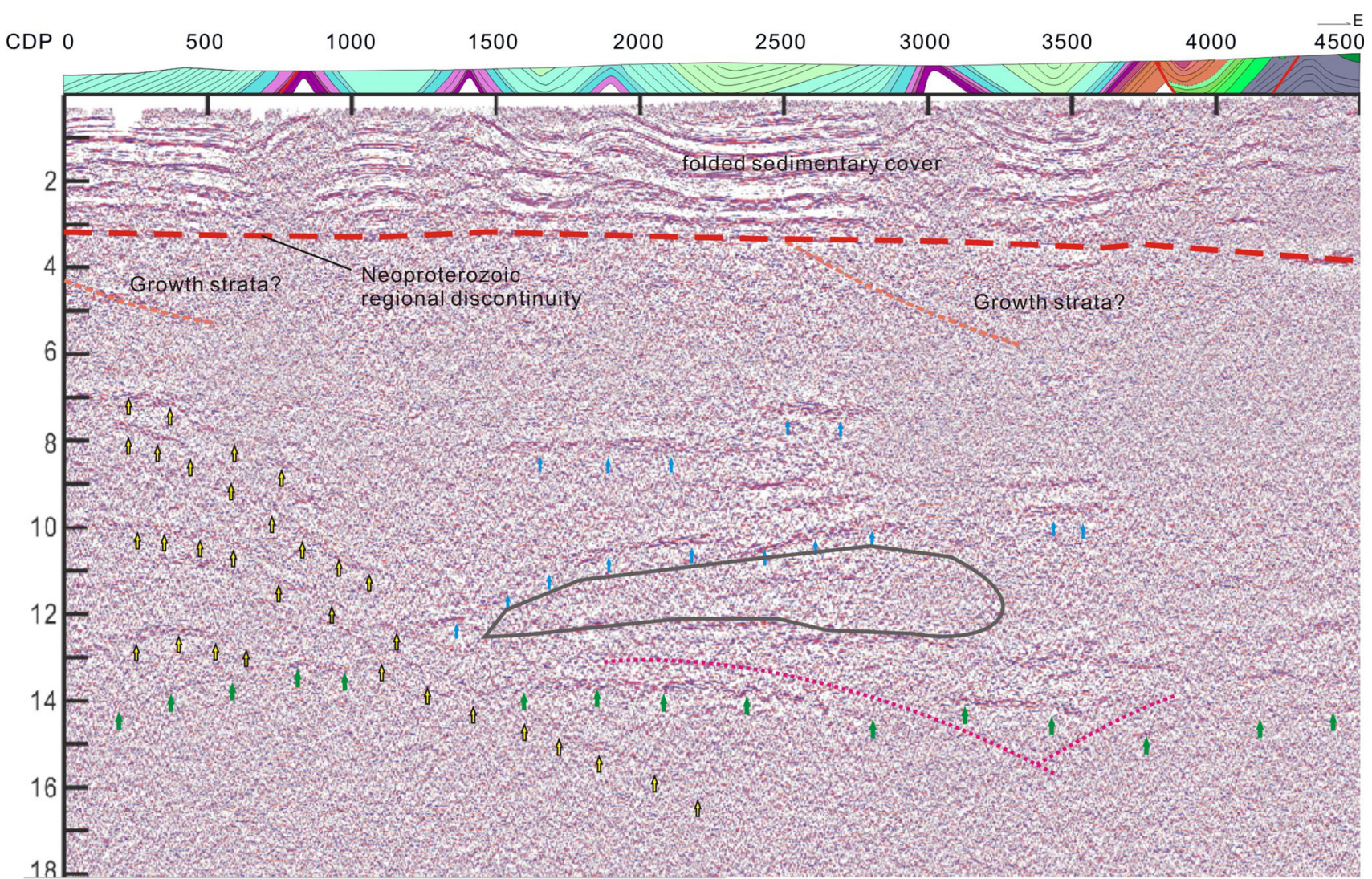

i South-dipping reflectors in the middle-lower crust. 1 Green arrows point to subhorizontal lower-crustal reflectors.

$\uparrow$ Blue arrows point to Moho. ".. South-dipping reflectors right-beneath the regional discontinuity. $\cdots$ Interpreted Moho offset.

The transparent zone in the lower crust. The legend of the geological section is as the same as Fig. 2

Fig. 3 Seismic profile and lables of main geologic features discussed in text

Therefore, the Qiyue fault is not the main fault separated the comb-like fold and the trough-like fold, which is also truncated by the decollement. The decollement is along the bottom of the Permian strata upwards the surface, dips at $\sim 30^{\circ}$. In the zone of comb-like fold belt, fault propagation faulting accommodated the crustal deformation in the upper plate, while the thrust imbricating worked in the lower plate. In this study, we concentrate on the Precambrian evolution of Yangtze block, thus the more details of the sedimentary cover will be discussed in another paper. 


\subsubsection{Middle crust}

Below the unconformity to the $20 \mathrm{~km}$ ( $7 \mathrm{~s}$, assuming the crustal average velocity is $\sim 6.0 \mathrm{~km} / \mathrm{s}$ ), the zone shows transparent almost except the southward-dipping reflectors below CDP 0-500 and 2500-3300, combined with the regional stratigraphy, we assume they represent the growth-strata of Lengjiaxi and Banxi groups (Neoproterozoic, ca. 820-785 Ma), which are the upper metamorphosed basement. Lengjiaxi group are stronglydeformed including metasandstones, siltstones and slates with metamorphosed mafic-ultramafic volcanic intercalations, which is volcanic-sedimentary foundation, different tectonic models have been proposed for the tectonic setting of the Lengjiaxi group, including a plume-rift model, a slab-arc model and a plate-rift model (Zhao and Cawood 2012), anyway, the deposit environment of the Lengjiaxi group is extensional; Banxi group is a suit of flysch sediment, consist mainly of shallow metamorphic (low greenschist facies) purple and gray-green sandstones, then the tilted reflectors may represent growth strata in a halfgraben, the other finely laminated regions in the seismic profile is weak as their boundaries are less well defined: they may either be bounded by normal faults or intruded by plutons, combined with the other information, we prefer to interpret them as fault-bounded rift basins (Dong et al. 2013).

\subsubsection{Lower crust}

At the northern end of the profile, a set of southwarddipping reflectors developed between 20-45 km (7-15 s), which can be traced northward crossing Huaying fault (Wang et al. 2011). A set of sub-horizontal reflectors developed in the middle of the profile, most of which are very clear, except the zone below CDP 2615 is a little weak, which may be a homogeneous granite or not imaged by the insufficient exploration energy.

\subsubsection{Moho and upper mantle}

The Moho is well defined as the bottom surface of a continuous zone undulating slightly between 36 and $42 \mathrm{~km}$ (ca. 12-14 s), it displays wary geometry in the north and is offset by the thrust shear zones southward, there are no obvious links between Moho-offset faults and upper crustal structures, but they do have a link with the southwarddipping reflectors northward (Gao et al. 2013).

\subsection{Meaning of the middle-lower crust}

The region around the Sichuan basin experienced strong deformation before Cenozoic related to either far-field stresses by Jurassic collision of Neo-Tethys terranes along the southern margin of South China or the continued convergence of north and south China after the Triassic closure of the Paleo-Tethys (Dong et al. 2013). The fold belt are typically thin-skinned, which represents the regional unconformity acted as the decollement limited the subsequent tectonic events didn't influence the pre-Nanhua crust. Mantle reflections have been reported beneath Phanerozoic and Proterozoic crust and attributed to shear zones associated with both extension and compression (BABEL Working Group 1990; Flack et al. 1990; Hammer et al. 2010; McGeary and Warner 1985), which may originated at the upper surface of an eclogitic slab embedded in the mantle by subduction (Morgan et al. 1994), or arisen from a shear zone created by thrusting of a lower plate down into the mantle (Calvert et al. 1995). The mantle reflectors extend to at least $48 \mathrm{~km}$ depth in the western zone, Combined with the overlying crustal reflectivity, the mantle reflectors maybe indicate a frozen collision zone before the deposit of the Lengjiaxi group.

\section{Mid-lower crustal gravity anomalies}

The seismic profile indicates the potential frozen collision zone frontier, which urges us to obtain the middle-lower crust anomalies of the SCB to verify the difference to the sides of the Chongqing-Huaying line, since Bouguer gravity anomalies present the crustal density distribution structure and tectonics. We assembled the previous deep seismic sounding profiles around the Sichuan basin. And then after reductions we obtained the fluctuating depth contours of the Moho interface and the bottom interface of sediment cover (Fig. 4; Xiong et al. 2015a). We then calculated forwardly the anomalies caused by sedimentary cover and the Moho surface and then stripped them from the Bouguer gravity anomalies, to obtain the gravity anomalies reflecting the crustal structure and tectonic features between the sedimentary cover and the Moho surface (Xiong et al. 2015a, b). The detailed gravity source and process is introduced in Fig. 4 (Xiong et al. 2015b).

The results show that the residual gravity anomalies in the basin are characterized by blocks in East-West and the amplitude of -32 to $206 \mathrm{mGal}$. To the west of the Chongqing-Huaying line, two high gravity anomalies traps are presented respectively in the north and south. The high traps centered at Neijiang, Suining, Nanchong and Daxian with a striking of $\mathrm{NE}$ direction and the values up to 170 mGal. However, to the east of the line, only one high gravity anomalies trap is presented, which is NNE-trending with the amplitude up to $190 \mathrm{mGal}$ (Fig. 5). Therefore, the characteristics of the residual gravity anomalies are different between the west and east sides of the Chongqing- 

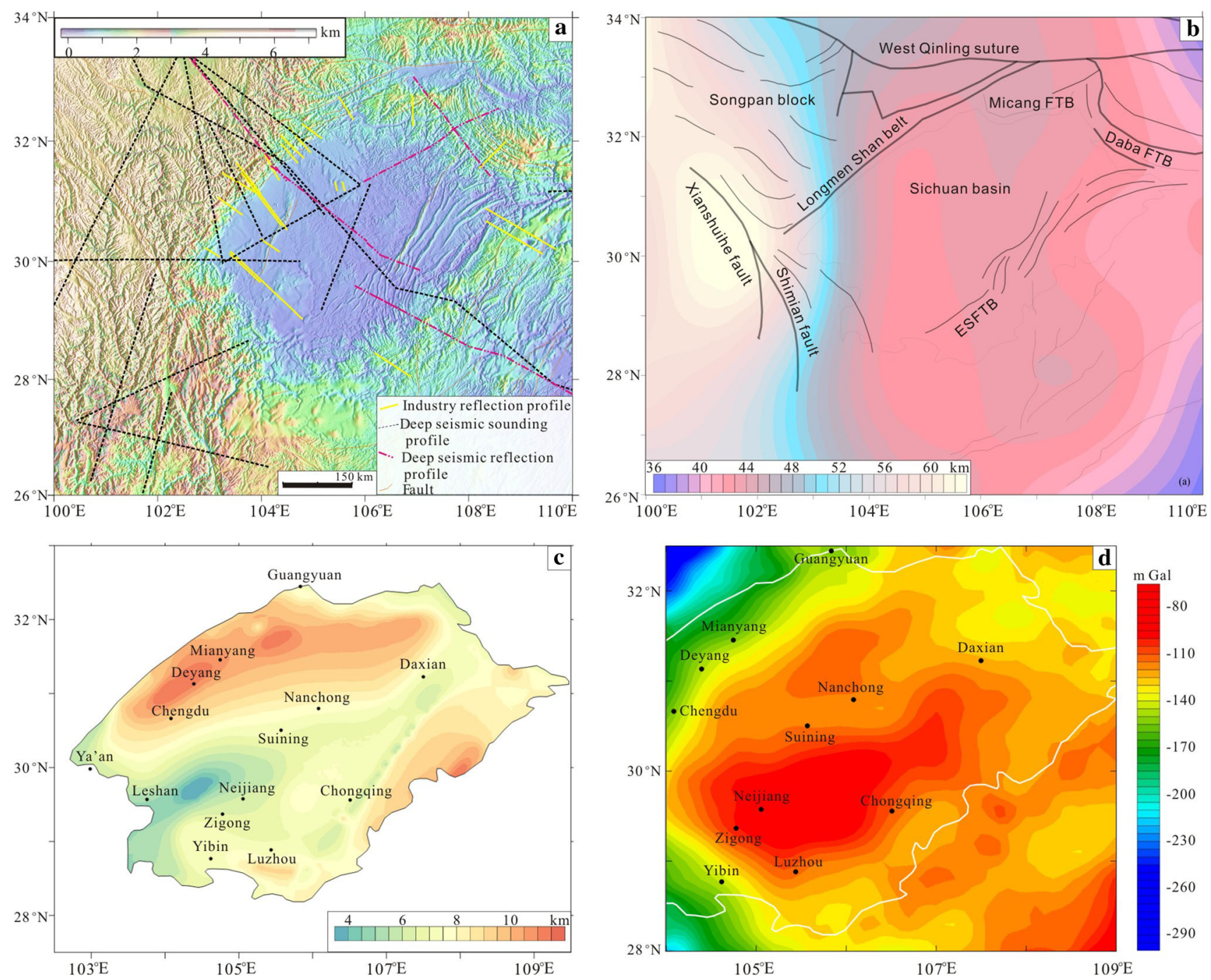

Fig. 4 a The sketch map of distribution of the deep seismic reflection profiles and wide-angle reflection and refraction profiles around the Sichuan basin; $\mathbf{b}$ The Moho depth contour map of the Sichuan basin and adjacent regions; $\mathbf{c}$ The sedimentary cover thickness contour map of the Sichuan basin; $\mathbf{d}$ The gravity anomaly contour map of the Sichuan basin and adjacent regions. FTB fold thrust belt

Huaying Line. From east to west, the traps become narrow and the axis features of these traps differ from each other, indicating that the crustal structures are different between both sides. The Chongqing-Huaying line is the connective zone of the high traps on both sides. The anomalies along this line is relatively low and trends in the NE direction. Usually, the lower gravity anomaly indicates the downwarping of the crust or intruded into the mantle (Li et al. 2015). We suggest the zone of the lower gravity anomaly reflects a possible blind fault zone in the subsurface, which separated the ancient continent around this line into two different oldlands.

\section{Discussion}

The result of the middle-lower crust gravity anomalies of the Sichuan basin is consistent with the finding of the deep seismic reflection profile. To the north of this seismic survey line, a $330 \mathrm{~km}$ long deep seismic reflection profile also revealed a east-dipping mantle suture near the Huaying fault beneath the Sichuan basin (Gao et al. 2013). The result of the aeromagnetic anomaly also showed the basement of the Sichuan basin is heterogeneous on the whole (Zhang et al. 2013; Gu and Wang 2014; Gu et al. 2014): the region to the west of the Chongqing-Huaying is with a high 


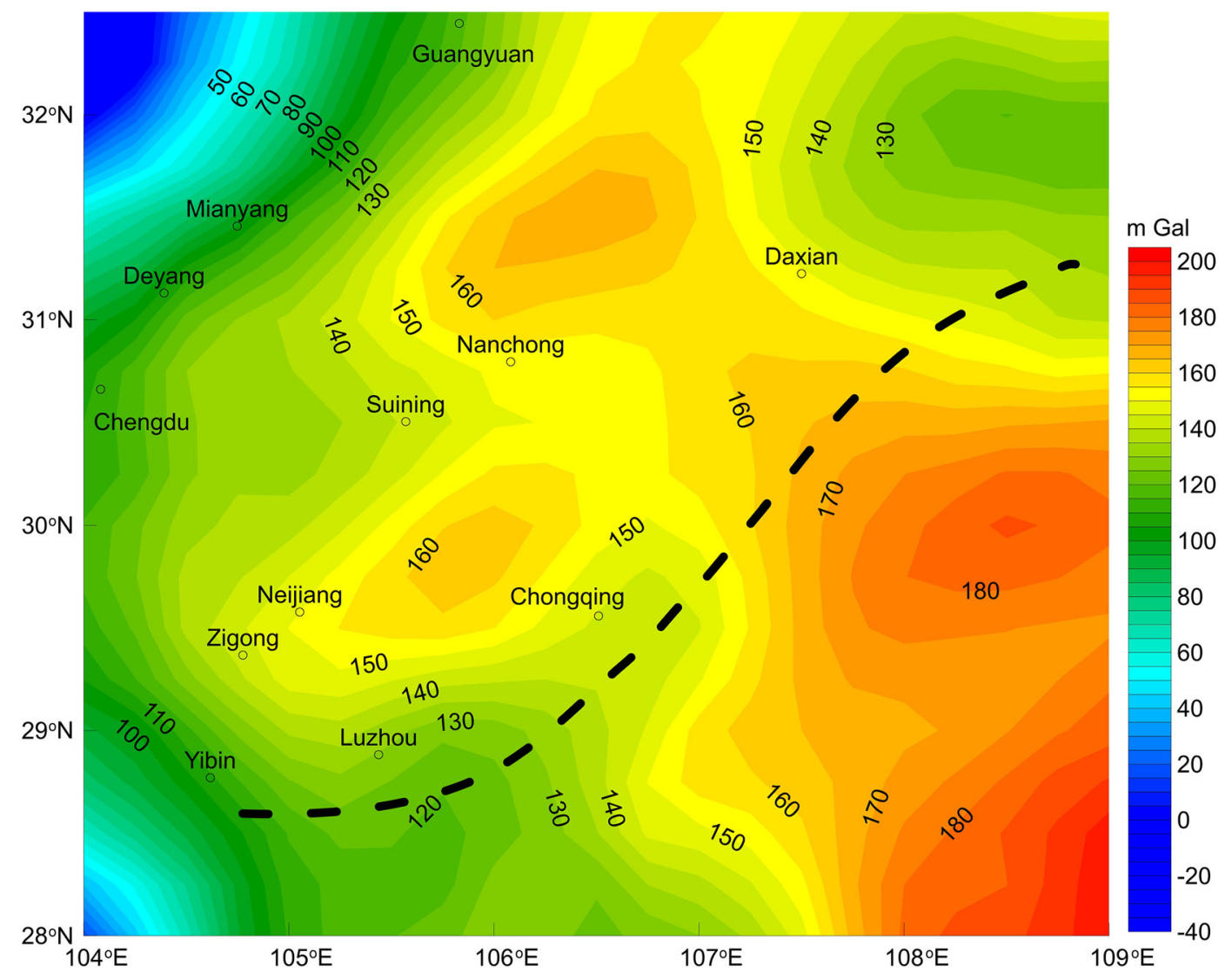

Fig. 5 The middle-lower curstal gravity anomaly of the Sichuan basin and adjacent regions (Xiong et al. 2015b). The black dash line indicates the distinctive difference between the western and eastern parts

aeromagnetic anomaly centered in Nanchong and Daxian, while the region to the east is with a high aeromagnetic anomaly centered in Shizhu. The positive aeromagnetic anomalies usually reveal the regional structure of the metamorphosed basement. Therefore, the aeromagnetic anomalies also indicated the basement of the Sichuan basin is not united (Gu and Wang 2014). The Paleoproterozoic gneisses reported in the western part of the Yangtze block implied the presence of old continental nuclei in both eastern Yangtze block and western Yangtze block consistently (Wu et al. 2012), 2050-2400 Ma events were absent in eastern part (Wu et al. 2012), which imply that the West Yangtze and East Yangtze had different evolution history before $\sim 2.0 \mathrm{Ga}$. The survey of Paleoproterozoic ages throughout the Yangtze block suggests the metamorphic and magmatic activities in 2.0-1.8 Ga (Zhang et al. 2006b), and an active-type continental margin formed in the western part of the Yangtze when the passive-type continental margin in the eastern part of the Yangtze speculated by Wu et al. (2012), which implied a collision zone was resulted in the final arc-continental melting at $\sim 2.0 \mathrm{Ga}$ linked to the assembly of supercontinent Columbia. The south-dipping mantle reflectors maybe represent a remnant of the descending plate follow closure of the subduction zone. Although the sub-horizontal reflectors to the right of the mantle reflectors are still debated, which may present the ductile shear zones or the magmatic sills. According to the regional stress field, the developed ductile shear zones should be more south-dipping than north-dipping. Thus we prefer the latter formed by the relamination of the subducted felsic continental crust into the base of the crust in the upper plate, coherent with the geochemistry features of the granite intruded into the Kongling complex aged $\sim 1.85 \mathrm{Ga}$ which exhibits the post-orogenic A-type affinity (Peng et al. 2012; Xiong et al. 2009; Zhang et al. 2011). The granites may experience the granulitization or gneissification in the subsequent tectonic events, which can make them stay stable in the middle or lower crust. The Moho of the stable block usually is a sharp discontinuity or transparent (Cook 2002), but the Moho to the southern of the south-dipping zone featured as a series of laminated reflectors is not the typical type of the stable block, jointly with the ultramafic zone beneath the Moho showed by the deep seismic sounding profile (Fig. 6; Yuan and Egorov 2002), which may correspond to the underplating of the plutons to the base of the crust related 


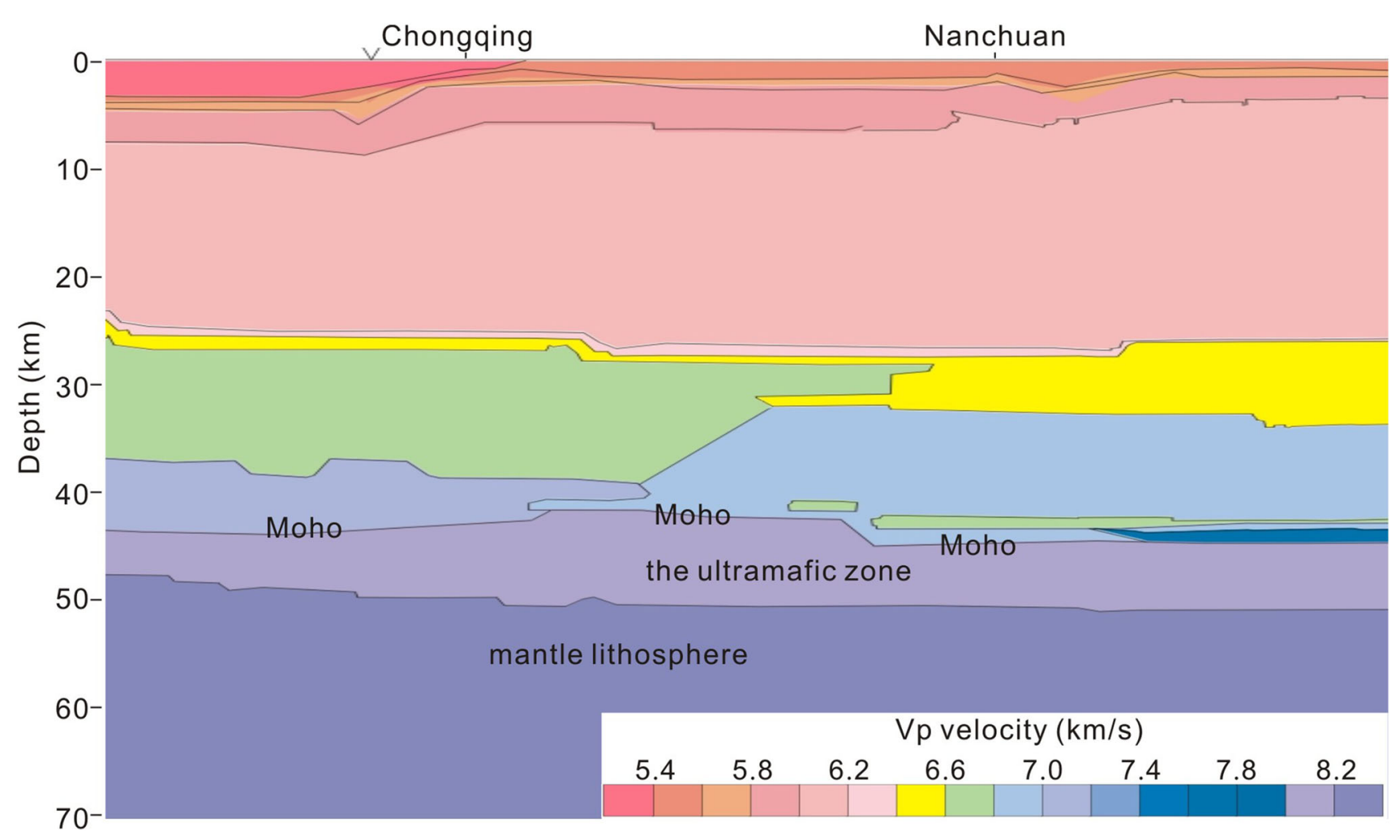

Fig. 6 The 2D Vp velocity crustal structure of eastern Sichuan fold belt (ESFB) (Modified from Yuan and Egorov 2002)

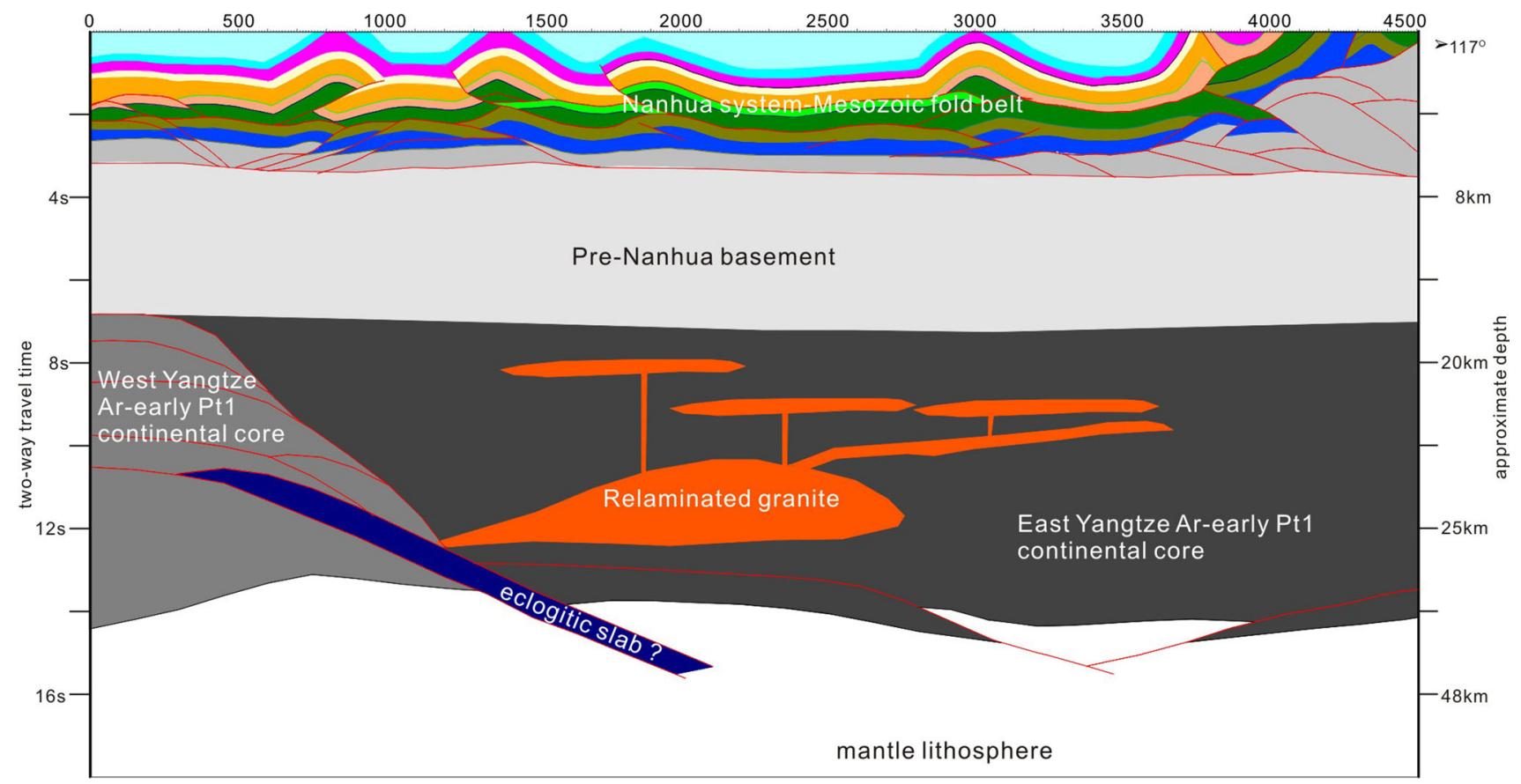

Fig. 7 Interpreted cross section of ESFTB

to the $\sim 2.0 \mathrm{Ga}$ collision or postcollisional events. The Yangtze block was finally amalgamated, acted as the lower basement after the upper deformed basement was formed by the consolidation of the Lengjiaxi and Banxi Groups in Neoproterozoic, then the sedimentary cover deposited on the top of the double basement. 


\section{Conclusion}

By combining the seismic data with gravity anomaly, we are able to propose a frozen subduction zone existed within the Yangtze block, which imply the amalgamation of the West and East Yangtze blocks before the deposit of the Lengjiaxi group (Fig. 7). The previous aeromagnetic anomalies and geochemical characteristics of the ArcheanPaleoproterozoic gneisses also support our supposition. During the subduction, the crustal materials of West Yangtze block was took back into the lower crust of East Yangtze block, formed the relamination within the lower crust of East Yangtze block, the Paleoproterozoic Moho was underplated by the upwelling magmas. The first-stage amalgamation also represented the formation of the lower basement. Afterwards, the Yangtze block experienced the unique tectonic events, including the melting with the Cathaysia block, the formation of the upper deformed basement, and the Phanerozoic folding. The frozen subduction zone then changed to a shear zone, accommodated the lower crustal shortening along with the decollement at the base of the Nanhua system functioned in the upper sedimentary cover. This new subduction model will give us a different insight to consider the position of the South China during the forming of the supercontinent Columbia.

Acknowledgments This paper was funded by the National Natural Science Foundation of China (Nos. 41104056, 41374093, 40974060, 41574093) and basic scientific research fund of IG, CAGS (J1119).

Open Access This article is distributed under the terms of the Creative Commons Attribution 4.0 International License (http://crea tivecommons.org/licenses/by/4.0/), which permits unrestricted use, distribution, and reproduction in any medium, provided you give appropriate credit to the original author(s) and the source, provide a link to the Creative Commons license, and indicate if changes were made.

\section{References}

BABEL Working Group (1990) Evidence for early Proterozoic plate tectonics from seismic reflection profiles in the Baltic shield. Nature 348(6296):34-38

Calvert AJ, Sawyer EW, Davis WJ, Ludden JN (1995) Archaean subduction inferred from seismic images of a mantle suture in the Superior Province. Nature 375(6533):670-674

Charvet J (2013) The Neoproterozoic-Early Paleozoic tectonic evolution of the South China Block: an overview. Journal of Asian Earth Sciences in press

Charvet J, Shu L, Shi Y, Guo L, Faure M (1996) The building of south China: collision of Yangzi and Cathaysia blocks, problems and tentative answers. J SE Asian Earth Sci 13(3-5):223-235

Cook FA (2002) Fine structure of the continental reflection Moho. Geol Soc Am Bull 114(1):64-79

Cook FA, van der Velden AJ, Hall KW, Roberts BJ (1999) Frozen subduction in Canada's Northwest Territories: Lithoprobe deep lithospheric reflection profiling of the western Canadian Shield. Tectonics 18(1):1-24

Dong S, Gao R, Yin A, Guo T, Zhang Y, Hu J, Li J, Shi W, Li Q (2013) What drove continued continent-continent convergence after ocean closure? Insights from high-resolution seismicreflection profiling across the Daba Shan in central China. Geology 41:671-674

Flack CA, Klemperer SL, McGeary SE, Snyder DB, Warner MR (1990) Reflections from mantle fault zones around the British Isles. Geology 18(6):528-532

Gao R, Chen C, Lu Z, and Brown L (2013) SINOPROBE deep reflection profile reveals a neo-proterozoic subduction zone beneath the Sichuan Basin. Acta Geol Sinica (English Edition), 87(supp.): 126

Greentree MR, Li Z-X (2008) The oldest known rocks in southwestern China: SHRIMP U-Pb magmatic crystallisation age and detrital provenance analysis of the Paleoproterozoic Dahongshan Group. J Asian Earth Sci 33(5-6):289-302

Gu ZD, Wang ZC (2014) The discovery of Neoproterozic extensional structures and its significance for gas exploration in the Central Sichuan Block, Sichuan basin, South China. Sci China: Earth Sci 44(10):2210-2220 (in Chinese with English abstract)

Gu ZD, Zhang W, Yuan M (2014) Zircon SHRIMP U-Pb dating of basal granite and its gelogical significance in Weiyuan area of Sichuan Basin. Chin J. Geol 49(1):202-213 (in Chinese with English abstract)

Guo LZ, Shi YS, Ma RS (1980) The geotectonic framework and crustal evolution of South China. Scientific Paper on Geology for International Exchange. Geological Publishing House, Beijing, pp 109-116 (in Chinese)

Hammer PTC, Clowes RM, Cook FA, van der Velden AJ, Vasudevan K (2010) The Lithoprobe trans-continental lithospheric cross sections: imaging the internal structure of the North American continent. Can J Earth Sci 47(5):821-857

Jiao W, Wu Y, Yang S, Peng M, Wang J (2009) The oldest basement rock in the Yangtze Craton revealed by zircon $\mathrm{U}-\mathrm{Pb}$ age and $\mathrm{Hf}$ isotope composition. Sci China Ser D 52(9):1393-1399

Juhlin C, Elming S-Å, Mellqvist C, Öhlander B, Weihed P, Wikström A (2002) Crustal reflectivity near the Archaean-Proterozoic boundary in northern Sweden and implications for the tectonic evolution of the area. Geophys J Int 150(1):180-197

Li ZJ, Xu RG, Chen S, Yang G, Yan WS, Yuan JH, Zhang Y, Gu ZW (2015) Study on gravity anomaly of central Mongolia profile. J Geodesy Geodyn 35(5):866-870 (in Chinese with English abstract)

McGeary S, Warner MR (1985) Seismic profiling the continental lithosphere. Nature 317(6040):795-797

Morgan JV, Hadwin M, Warner MR, Barton PJ, Morgan RPL (1994) The polarity of deep seismic reflections from the lithospheric mantle: evidence for a relict subduction zone. Tectonophysics 232(1-4):319-328

Peng M, Wu Y, Gao S, Zhang H, Wang J, Liu X, Gong H, Zhou L, Hu Z, Liu Y, Yuan H (2012) Geochemistry, zircon U-Pb age and Hf isotope compositions of Paleoproterozoic aluminous A-type granites from the Kongling terrain, Yangtze Block: Constraints on petrogenesis and geologic implications. Gondwana Res 22(1):140-151

Qiu YM, Gao S, McNaughton NJ, Groves DI, Ling W (2000) First evidence of $>3.2 \mathrm{Ga}$ continental crust in the Yangtze craton of south China and its implications for Archean crustal evolution and Phanerozoic tectonics. Geology 28(1):11-14

Wang HY, Gao R, Feng SY, Lu ZW, Xiong XS, Zhu XS, Li WH, Ma C (2011) Research of SinoProbe deep seismic reflection profiling across the Sichuan basin and Xuefeng mountain. 27th annual meeting of the Chinese Geophysical Society, Changsha, pp 143-144 
Wang LJ, Griffin WL, Yu JH, O’Reilly SY (2013) U-Pb and Lu-Hf isotopes in detrital zircon from Neoproterozoic sedimentary rocks in the northern Yangtze Block: Implications for Precambrian crustal evolution. Gondwana Res 23(4):1261-1272

Warner M, Morgan J, Barton P, Morgan P, Price C, Jones K (1996) Seismic reflections from the mantle represent relict subduction zones within the continental lithosphere. Geology 24(1):39-42

White DJ, Zwanzig HV, Hajnal Z (2000) Crustal suture preserved in the Paleoproterozoic Trans-Hudson orogen, Canada. Geology 28(6):527-530

Wu Y, Gao S, Zhang H, Zheng J, Liu X, Wang H, Gong H, Zhou L, Yuan H (2012) Geochemistry and zircon U-Pb geochronology of Paleoproterozoic arc related granitoid in the Northwestern Yangtze Block and its geological implications. Precambr Res 200-203:26-37

Xiong Q, Zheng J, Yu C, Su Y, Tang H, Zhang Z (2009) Zircon U-Pb age and Hf isotope of Quanyishang A-type granite in Yichang: signification for the Yangtze continental cratonization in Paleoproterozoic. Chin Sci Bull 54(3):436-446

Xiong X, Gao R, Guo L, Wang H, Jiang Z (2015a) The deep structure feature of the Sichuan Basin and Adjacent Orogens. Acta Geol Sinica 89(4):1153-1164

Xiong X, Gao R, Zhang J, Wang H, Guo L (2015b) The structure of Mid-lower crust is different between western and eastern blocks of Sichuan basin. Chin J Geophys 58(7):2413-2423 (in Chinese with English abstract)

Yuan X, Egorov A (2002) GEMOC. A short introduction to Global Geoscience Transect 21: Arctic Ocean-Eurasia-Pacific Ocean. Science Press, Beijing
Yuan X-C, Simon K, Teng L, Wen-Bang Liu L-X, Emily C (2003) Crustal structure and exhumation of the Dabie Shan ultrahighpressure orogen, eastern China, from seismic reflection profiling. Geology 31(5):435-438

Zhang S-B, Zheng Y-F, Wu Y-B, Zhao Z-F, Gao S, Wu F-Y (2006a) Zircon isotope evidence for $\geq 3.5 \mathrm{Ga}$ continental crust in the Yangtze craton of China. Precambr Res 146(1-2):16-34

Zhang S-B, Zheng Y-F, Wu Y-B, Zhao Z-F, Gao S, Wu F-Y (2006b) Zircon $\mathrm{U}-\mathrm{Pb}$ age and $\mathrm{Hf}-\mathrm{O}$ isotope evidence for Paleoproterozoic metamorphic event in South China. Precambr Res 151(3-4): 265-288

Zhang L, Ma C, Wang L, She Z, Wang S (2011) Discovery of Paleoproterozoic rapakivi granite on the northern margin of the Yangtze block and its geological significance. Chin Sci Bull 56(3):306-318

Zhang J, Rui G, Qiusheng LI, Ye G, Wang H, Wenhui LI (2013) Characteristic of gravity and magnetic anomalies in the Daba Shan and the Sichuan basin, China: implication for architecture of the Daba Shan. Acta Geol Sinica 87(4):1154-1161

Zhao G, Cawood PA (2012) Precambrian geology of China. Precambr Res 222-223:13-54

Zheng J, Griffin WL, O'Reilly SY, Zhang M, Pearson N, Pan Y (2006) Widespread Archean basement beneath the Yangtze craton. Geology 34(6):417-420

Zhou XM, Zhu YH (1993) Petrological evidences of Neoproterozoic collision-orogenic and suture belts in southeastern China. In: Li JL (ed) Lithospheric structures and geological evolution in continent from Southeastern China. Metallurgical Industry Press, Beijing, pp 87-97 